\title{
TAFSIR SAINTIFIK TENTANG PUASA RAMADHAN
}

(Studi atas Kitab Tafsir Quran Karim Karya Mahmud Yunus)

\author{
M. Dalip \\ Email : dalipstainmajene.ac.id
}

\begin{abstract}
This article describes the scientific interpretation of Mahmud Yunus to the verses of the Qur'an in the interpretation of the Qur'an. He seeks to maintain the harmony of the Qur'an with science while showing the readers that modern scientific discoveries have been stated or hinted at in the Qur'an. Mahmud Yunus's scientific interpretation in his commentary does not follow the model as has been adopted by other popular scientific interpreters, such as Tantawi Jauhari. In interpreting the Qur'an scientifically, Mahmud Yunus took his own style. He tried to avoid the scientific explanation by each word. He only explained the verses of the Qur'an and then related them to the development of modern science. Mahmud Yunus's style of interpreting the Qur'an will be seen when interpreting the QS. surah al-Baqarah / 2 verses 183-185. For Mahmud Yunus, linking the Qur'an with scientific knowledge is one of the efforts to encourage Muslims to master modern science, and can arouse Muslims' passion to advance and catch up to later be aligned with the western world.
\end{abstract}

Keywords: Mahmud Yunus, Scientific, Interpretation 


\begin{abstract}
Abstrak
Artikel ini menjelaskan interpretasi ilmiah dari Mahmud Yunus ke ayat-ayat Al-Qur'an dalam penafsiran Al-Qur'an. Dia berusaha untuk menjaga harmoni Al-Qur'an dengan sains sambil menunjukkan kepada para pembaca bahwa penemuan-penemuan ilmiah modern telah dinyatakan atau disiratkan dalam Al-Qur'an. Penafsiran ilmiah Mahmud Yunus dalam komentarnya tidak mengikuti model seperti yang telah diadopsi oleh penafsir ilmiah populer lainnya, seperti Tantawi Jauhari. Dalam menafsirkan Alquran secara ilmiah, Mahmud Yunus mengambil gayanya sendiri. Dia berusaha menghindari penjelasan ilmiah dari setiap kata. Dia hanya menjelaskan ayat-ayat Alquran dan kemudian menghubungkannya dengan perkembangan sains modern. Gaya Mahmud Yunus dalam menafsirkan Al-Qur'an akan terlihat ketika menafsirkan QS. surah al-Baqarah / 2 ayat 183-185. Bagi Mahmud Yunus, mengaitkan Alquran dengan pengetahuan ilmiah adalah salah satu upaya untuk mendorong umat Islam untuk menguasai ilmu pengetahuan modern, dan dapat membangkitkan hasrat umat Islam untuk maju dan mengejar ketinggalan untuk kemudian disejajarkan dengan dunia barat.
\end{abstract}

Kata Kunci : Mahmud Yunus, Saintifik, dan Penafsiran. 


\section{Pendahuluan}

Sarjana-sarjana Muslim telah banyak menghasilkan karyakarya agung di bidang tafsir, dari masa klasik, seperti Jami' alBayan fi Tafsir al-Qur'an karangan Imam al-Thabari, Mafatih alGhaib karangan Imam Fakhr al-Din al-Razi dan al-Kasysyaf an Haqaiq al-Tanzil Karangan Imam al-Zamakhsyari, hingga modern, sepertifi Dzilal al-Qur'an karangan Sayyid Quthb, Tafsir alMaraghi karangan Mustafa al-Maraghi, Tafsir al-Mizan karangan 'Allamah al-Thabathaba'i, dan di Indonesia sendiri seperti Tafsir al-Azhar karangan Buya Hamka, Tafsir al-Misbah karangan M. Quraish Shihab, dan lain-lain. Berbagai metode dan pendekatan telah dilakukan oleh mereka, dan telah memperkaya secara signifikan khazanah penafsiran al-Qur'an yang dimiliki oleh umat Islam selama ini.

Dalam artikel ini, penulis ingin mencoba membahas sebuah tafsir al-Qur'an yang bercorak saintifik, yang di sini akan diwakili oleh seorang penafsir Nusantara Mahmud Yunus (1899-1982 M) dalam kitabnya yang berjudul Tafsir Quran Karim. Kajian ini, menurut penulis, penting sebagai sebuah upaya memperluas 
wawasan tafsir al-Qur'an, khususnya tafsir yang pernah tumbuh di Indonesia. Selain itu, juga menjadi pengetahuan bahwa al-Qur'an yang merupakan kitab suci umat Islam itu, ternyata bisa didekati dari berbagai perspektif. Salah satu perspektif yang penulis maksud adalah upaya menyingkap makna al-Qur'an dengan menghubungkannya dengan pengetahuan-pengetahuan ilmiah yang oleh penulis sendiri menyebutnya sebagai tafsirs aintifik.

\section{Sekilas tentang Penulisan Tafsir Karya Mahmud Yunus.}

Tafsir Qur'an Karim, demikian karya Mahmud Yunus ini disebut, walaupun boleh jadi dianggap sebagai tafsir yang sangat sederhana, tetapi penyajiannya dalam menjelaskan ayat-ayat alQur'an dapat dikatakan melampaui masanya. Mahmud Yunus dalam beberapa penafsirannya berusaha dengan keras menghubungkan ayat-ayat al-Qur'an dengan pengetahuanpengetahuan ilmiah yang berkembang pada masanya. Ia menjelaskan ayat-ayat al-Qur'an dengan pengetahuanpengetahuan ilmiah yang dimilikinya.Tidak sedikit dalam tafsirnya akan ditemukan penjelasan-penjelasan yang diambil dari 
para ilmuwan Barat. Ia seringkali menyebut para ilmuwan Barat sebagai ulama-ulama Eropa. Bagi Mahmud Yunus gelar ulama tidak hanya disematkan kepada orang-orang Islam saja, akan tetapi sebutan ulama layak disandang oleh siapa saja yang memiliki ilmu pengetahuan tidak terkecuali ilmuwan dari Eropa.

Mahmud Yunus dalam penafsiran ilmiahnya tidak sepenuhnya mengikuti model sebagaimana yang dilakukan oleh para mufassir ilmiah populer lainnya. Karya tafsir Mahmud Yunus ini berbeda dengan penjelasan-penjelasan ilmiah sebagaimana misalnya yang terdapat dalam kitab tafsir al-Jawahir fi Tafsir alQur'an al-Karimkarya Tantawi Jauhari. Dalam tafsir al-Jawahir akan ditemukan berbagai penjelasan ilmiah terhadap ayat-ayat alQur'an disertai dengan ilustrasi gambar-gambar, antara lain berupa benda-benda antariksa.

Dalam pengantar tafsirnya, Tantawi Jauhari menyebut bahwa tafsirnya dimaksudkan sebagai kerangka penyesuaian penjelasan ayat-ayat dengan perkembangan ilmu pengetahuan, yang pada masanya telah banyak menyingkap berbagai misteri alam. Tujuannya adalah agar kaum muslim, terutama generasi 
muda, mampu menyelidiki misteri-misteri langit dan keindahan bumi agar Allah mengangkat peradaban kaum muslim sehingga dapat menandingi Perancis dalam soal pertanian, kedokteran, pertambangan, matematika, teknologi, astronomi, industri, dan ilmu-ilmu lainnya. ${ }^{1}$

Ciri yang sangat menonjol dalam karya Tantawi Jauhari itu adalah "ekstra komentar" -nya tercermin pada hampir seluruh ayat al-Qur'an, terutama yang menyangkut alam dengan cara menyantolkan penjelasan ilmiah pada setiap ayat atau kosa kata yang menyebut alam, bahkan tidak jarang "over komentar". ${ }^{2}$

Corak tafsir ilmiah yang diketengahkan Mahmud Yunus dalam tafsirnya tidak mengikuti sebagaimana karya tafsir yang ditulis Tantawi Jauhari. Mungkin Mahmud Yunus menyadari bahwa karya tafsir yang ditulis Tantawi Jauhari itu ternyata mendapat celaan dan kecaman yang luar biasa dari kalangan pemerhati tafsir al-Qur'an itu sendiri. Tidak mengherankan jika kemudian sebagian ulama menolak kitab tafsir itu dan menilainya

${ }^{1}$ Tantawi Jauhari, al-Jawahir fi al-Tafsir al-Qur'an al-Karim, Vol.I (Kairo: Dar al-Fikr li al-Taba' ah wa al-Nasyr wa al-Tauzi'), h. 2-3

${ }^{2}$ Munzir Hitami, Pengantar Studi al-Qur'an: Teori dan Pendekatan, h. 119 
sebagai buku ensiklopedia. Bahkan Tantawi Jauhari dituduh telah mengesankan al-Qur'an sebagai kitab ilmu pengetahuan dan memasukkan teori-teori modern yang tidak dikenal oleh orang Arab dan tidak pula ada kaitannya dengan al-Qur'an. Kecaman yang paling keras datang dari Kerajaan Arab Saudi yang menolak kitab tersebut masuk ke negerinya. ${ }^{3}$

Dengan tidak mau mengambil resiko yang sama dengan karya tafsir Tantawi Jauhari, Mahmud Yunus menulis tafsir corak ilmiah dengan gayanya sendiri. Dalam karya tafsir Mahmud Yunus, penulisnya berusaha menghindari penjelasan ilmiah perkata. Ia hanya menjelaskan satu ayat atau beberapa ayat kemudian menghubungkannya dengan pengetahuan-pengetahuan yang memang sudah terbukti secara ilmiah.

Mahmud Yunus segera setelah menafsirkan ayat-ayat alQur'an secara ilmiah, ia selalu mengemukakan argumentasi bahwa ayat-ayat al-Qur'an itu tidak akan pernah bertentangan dengan ilmu pengetahuan dan membuktikan bahwa al-Qur'an itu bukanlah

${ }^{3}$ Muhammad Husain al-Zahabi, al-Tafsir wa al-Mufassirun, Jilid 2 (Kairo: Dar al-Kutub al-Hadisah, 1976), h. 508 
bikinan Nabi Muhammad saw, tetapi benar-benar wahyu yang berasal dari Allah swt.

Kritikan yang biasa dilontarkan kepada penafsir-penafsir ilmiah al-Qur'an adalah mereka membahas secara detail tentang kaitan al-Qur'an dengan sains modern. ${ }^{4}$ Ayat-ayat yang ada dalam al-Qur'an memiliki maknanya sendiri yang intrinsik dan hanya dapat dipahami dengan mempelajari dalam konteksnya sendiri, bukan sebagai pelajaran dalam pelbagai sains modern yang berbeda-beda atau bukti tekstual yang sejalan dengan teori mutakhir dalam lapangan pengetahuan modern. ${ }^{5}$

Penafsiran ilmiah terhadap ayat-ayat al-Qur'an yang dilakukan oleh Mahmud Yunus, lebih dilatari pada kekhawatirannya melihat kondisi umat Islam yang sangat tertinggal jauh dari orang-orang Barat di segala bidang kehidupan

${ }^{4}$ Salah satu tokoh yang cukup keras menolak penafsiran ilmiah terhadap al-Qur'an adalah Aisyah Abd Rahman yang lebih dikenal dengan nama samarannya Bint al-Syathi'. Menurutnya -sebagaimana yang telah ditulis oleh Achmad Khudori Soleh - al-Qur' an lebih merupakan ajaran moral yang bersifat abadi, bukan ajaran tentang fenomena alam atau sains modern, meski suatu ketika mungkin sejalan dengan itu. Achmad Khudori Soleh, Bint al-Syathi': Tafsir Tematik dalam Pemikiran Islam Kontemporer (Cet. I; Yogyakarta: Jendela: 2003), h. 115

${ }^{5}$ Achmad Khudori Soleh, Bint al-Syathi': Tafsir Tematik dalam Pemikiran Islam Kontemporer, h.115 
dan juga sekaligus sebagai salah satu bentuk pemberian motivasi kepada umat Islam khususnya Muslim Indonesia, untuk berupaya mengejar dan mempelajari ilmu pengetahuan modern. Ia berkeyakinan bahwa ternyata al-Qur'an yang notabene merupakan kitab suci umat Islam bersesuaian dengan pengetahuanpengetahuan itu. Sehingga menurut Mahmud Yunus, menafsirkan al-Qur'an dengan model menghubungkan ayat-ayat al-Qur'an dengan penemuan-penemuan ilmiah, dapat membangkitkan gairah umat Islam untuk maju dan mengejar ketertinggalan untuk kemudian sejajar dengan dunia Barat.

Mahmud Yunus setelah pulang dari rihlah ilmiahnya, tampaknya telah belajar banyak terhadap pembaharuan yang dilakukan oleh Muhammad Abduh di Mesir. Sebagaimana diketahui bahwa Muhammad Abduh orang yang membawa angin perubahan pemikiran di Negaranya, Mesir yang kemudian merambah ke beberapa dunia Muslim lainnya termasuk Indonesia. Dalam bidang tafsir Muhammad Abduh memberikan penekanan yang segar terhadap al-Qur'an sebagai sumber hidayah. Baginya, al-Qur'an merupakan sumber yang darinya kaum Muslimin 
semestinya mengambil gagasan-gagasan mereka tentang dunia sekarang dan dunia mendatang. ${ }^{6}$

Apa yang dilakukan Mahmud Yunus untuk menafsirkan alQur'an secara ilmiah merupakan gambaran keinginan sebagian dari umat Islam untuk selalu mendialogkan al-Qur'an sebagai teks yang terbatas dengan problem sosial kemanusiaan yang tak terbatas. Ini merupakan spirit tersendiri bagi dinamika kajian tafsir al-Qur'an. Hal ini karena al-Qur'an meskipun turun di masa lalu, dengan konteks dan lokalitas sosial budaya tertentu, ia mengandung nilai-nilai universal yang akan selalu relevan untuk setiap zaman dan tempat (shalih li kulli zaman wa makan). ${ }^{7}$

Kekhawatiran Mahmud Yunus akan ketertinggalan dunia Islam dari bangsa-bangsa Barat dapatlah dipahami mengingat bahwa sejak awal abad ke-19 hingga pertengahan abad ke-20, banyak komunitas Islam yang diserang dan dijajah oleh kolonial Eropa. Kolonialisme berdampak besar terhadap sektor politik,

${ }^{6}$ Taufik Adnan Amal, Rekonstruksi Sejarah al-Qur'an, h. 362

${ }^{7}$ Abdul Mustaqim, Epistemologi Tafsir Kontemporer (Cet.III;Yogyakarta:LKiS, 2012), h. 1 
sosial, ekonomi, dan budaya masyarakat. Dominasi Barat atas negeri-negeri Muslim merambah kesemua lini bidang kehidupan.

Sejak awal periode kolonialisasi, superioritas teknologi penjajah Eropa menjadi ancaman nyata. Untuk itulah banyak reformis muslim yang ingin memahami bagaimana bangsa Eropa dapat mengungguli orang Islam dalam pengetahuan teknologi, padahal orang Islam pernah menjadi pelopor pemikiran ilmiah beberapa abad sebelumnya. Banyak pembaru yang menyalahkan para pemimpin agama yang kurang terdidik dan percaya "takhayul" sebagai penyebabnya. Keinginan untuk membangkitkan pemikiran "rasional" di kalangan umat Islam mendorong sebagian ulama untuk menafsir ulang ayat-ayat alQur'an yang mereka anggap bertentangan dengan pemikiran ilmiah. $^{8}$

Pada abad ke -20, sejumlah ilmuwan dan ulama Islam beralih dari upaya mempertahankan keharmonisan al-Qur'an dengan ilmu pengetahuan pada upaya memperlihatkan bahwa

${ }^{8}$ Ingrid Mattson, The Story of the Qur'an, terj. R. Cecep Lukman Hakim dengan judul Ulummul Quran Zaman Kita: Pengantar untuk Memahami Konteks, Kisah, dan Sejarah Al-Qur'an, h. 312 
penemuan ilmiah modern telah dinyatakan atau diisyaratkan dalam al-Qur'an. ${ }^{9}$ Seperti yang telah dikutip sebelumnya bahwa seorang berkebangsaan Perancis yang bernama Maurice Bucaille dalam karyanya La Bible Le Coran et la Science, berargumen bahwa kemurnian wahyu al-Qur'an terbukti secara akurat dari gambaran ilmiah yang terkandung dalam ayat-ayatnya.

Banyak pembaru Islam yang berargumen bahwa al-Qur'an sangat menekankan penguasaan ilmu pengetahuan. Menarik diri dari kehidupan dunia ke dalam perenungan ruhani dan asketik, menurut mereka, merupakan bentuk pelanggaran terhadap pesan al-Qur'an. $^{10}$

${ }^{9}$ Ingrid Mattson, The Story of the Qur'an, terj. R. Cecep Lukman Hakim dengan judul Ulummul Quran Zaman Kita: Pengantar untuk Memahami Konteks, Kisah, dan Sejarah Al-Qur'an, h. 312

${ }^{10}$ Kritik semacam ini banyak, salah satunya datang dari M. Shamsher Ali, seorang Ketua Komite Isyarat Ilmiah dalam al-Qur'an. sebagaimana dikutip oleh Ingrid Mattson, ia pernah menulis bahwa persoalan yang mengganggu pikiran pemuda dan pemudi saat ini adalah: mengapa meskipun telah ada dorongan kuat dari al-Qur'an sejak awal ayatnya dalam surah al-Alaq ayat 1-5, sekitar dua pertiga umat Islam masih buta huruf, miskin, dan tertinggal jauh di bidang pengetahuan dan teknologi ? pertanyaan ini sangatlah penting dan perlu dijawab dengan tindakan nyata. Jawabannya mungkin bisa dilacak dari kenyataan bahwa meskipun kita membaca al-Qur'an, banyak diantara kita yang tidak memahami maknanya karena kurang pengetahuan. Allah sendiri menegaskan bahwa al-Qur'an adalah untuk “orang-orang yang berfikir".Ingrid Mattson, The Story of the Qur'an, diterjemahkan oleh R. Cecep Lukman Hakim dengan judul Ulummul Quran Zaman Kita: Pengantar untuk Memahami Konteks, Kisah, dan Sejarah Al-Qur'an (Cet. I; Jakarta: Zaman, 2013), h. 313 
Seperti yang telah djelaskan di atas, langkah yang ditempuh Mahmud Yunus dalam penafsiran ilmiahnya, tidak saja berusaha menjelaskan ayat-ayat al-Qur'an dengan cara menghubungkannya dengan ilmu pengetahuan, tetapi ia berupaya memperlihatkan bahwa penemuan-penemuan ilmiah modern itu telah dinyatakan dan diisyaratkan jauh-jauh sebelumnya oleh kitab suci umat islam, yaitu al-Qur'an.

Dalam pandangan penulis, Mahmud Yunus sepertinya memandang bahwa tafsir ilmi bukanlah sebuah usaha mencocokcocokkan ayat al-Qur'an dengan ilmu pengetahuan, tetapi tafsir ilmiah yang baik adalah menjelaskan ayat-ayat dari al-Qur'an dengan cara berupaya mempertahankan keharmonisan al-Qur'an dengan ilmu pengetahuan sambil memperlihatkan kepada pembaca bahwa penemuan-penemuan ilmiah modern itu telah dinyatakan atau diisyaratkan dalam al-Qur'an. Jadi, model tafsir ilmiah dalam karya Mahmud Yunus adalah lebih menitikberatkan kepada pemanfaatan penemuan-penemuan yang dihasilkan oleh ilmu pengetahuan (sains) untuk memahami dan menjelaskan ayat-ayat al-Qur'an. Seperti apa wujud penafsiran ilmiah Mahmud Yunus 
dalam karya tafsirnya ? berikut ini akan diketengahkan salah satu penafsiran saintifik Mahmud Yunus.

\section{Tafsir Saintifik Mahmud Yunus atas QS al-Baqarah/2: 183-185}

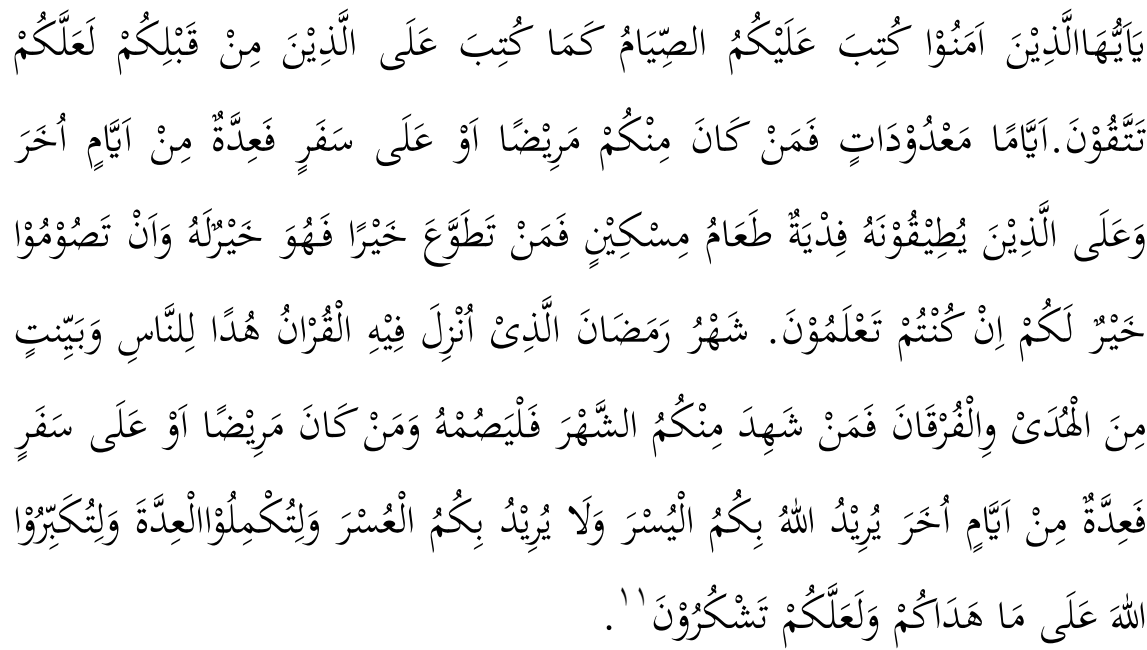

11 Artinya : Hai orang2 yang beriman, diperlukan atas kamu berpuasa, sebagaimana telah diperlukan atas orang2 yang sebelum kamu; mudah2an kamu bertaqwa. (183). (puasa itu) beberapa hari yang tertentu (29 atau 30). Barang siapa yang sakit diantara kamu atau dalam perjalanan, maka berpuasalah pada hari yang lain. Dan bagi orang2 yang kuasa berpuasa, tetapi amat berat melakukannya, (wajib) memberikan fidyah, (dengan memberi) makan seorang miskin. Barangsiapa mengerjakan sunat, maka itu amat baik baginya. Dan berpuasa itu lebih baik bagimu, jika kamu mengetahui. (184). (puasa itu) pada bulan Ramadhan yang diturunkan Qur'an pada bulan itu untuk petunjuk bagi manusia dan beberapa keterangan dari petunjuk dan membedakan antar yang hak dan yang batil. Barang siapa yang hadir diantara kamu di bulan Ramadhan hendaklah ia berpuasa. barang siapa yang sakit atau dalam perjalanan, maka berpuasalah pada hari yang lain. Allah menghendaki kemudahan bagimu dan tiada menghendaki kesukaran. Hendaklah kamu sempurnakan bilangan bulan 
Ayat 183 menjelaskan bahwa syariat puasa itu pernah diwajibkan kepada penganut agama sebelum Islam. Allah mewajibkan puasa kepada umat Nabi Musa dan Nabi Isa a.s. pada bulan Ramadan, kemudian umatnya menambahnya. Rahib mereka menambahnya sepuluh hari. Ketika sebagian rahib mereka menderita sakit, mereka bernazar akan berpuasa sepuluh hari jika Allah menyembuhkannya. Maka puasa umat Nasrani itu lima puluh hari. $^{12}$

Dalam perjalanan sejarahnya, puasa di kalangan penganut agama ini berkembang sejalan dengan perkembangan pemikiran di kalangan para pemimpinnya. Pada masa awal Islam, umat Islam berpuasa tiga hari pada setiap bulan, ditambah dengan hari 'Asyura, yakni tanggal 10 Muharram. Puasa seperti ini, menurut salah satu riwayat, adalah puasa seperti yang diwajibkan kepada orang-orang Yahudi. Kewajiban puasa bagi umat Islam akhirnya seperti yang dijelaskan dalam ayat di atas, yakni puasa di bulan Ramadan. $^{13}$

Kewajiban puasa Ramadan dimulai sejak berubahnya kiblat dari Masjid Aqsa (Palestina) ke Masjid Haram (Mekah) pada

itu dan hendaklah kamu besarkan Allah, karena petunjuk-Nya kepadamu; dan mudah2an kamu berterimah kasih kepada-Nya (185)

${ }^{12}$ Juhaya S. Praja, Tafsir Hikmah Seputar Ibadah, Muamalah, Jin, dan Manusia ( Cet. I; Bandung; PT Remaja Rosdakarya, 2000), h. 75

${ }^{13}$ Juhaya S. Praja, Tafsir Hikmah Seputar Ibadah, Muamalah, Jin, dan Manusia, h. 75 
tanggal 10 bulan Sya'ban tahun ke-2 Hijriyah. Nabi Muhammad saw. menunaikan puasa Ramadan sebanyak sembilan kali selama sembilan tahun. Nabi Muhammad wafat pada tahun ke-11 Hijriyah. $^{14}$

Awal ayat 184 menjelasan kapan puasa wajib itu harus dilaksanakan, yaitu pada hari-hari tertentu, yakni bulan Ramadan. Selanjutnya, ayat ini menjelaskan keringanan dalam pelaksanaan puasa Ramadan. Keringanan itu diberikan kepada (1) orang yang dalam keadaan sakit, (2) orang yang sedang dalam perjalanan yang disebut musafir, (3) orang yang tidak kuasa lagi menunaikan puasa.

Orang sakit yang mendapat keringanan dalam menunaikan ibadah puasa ialah mereka yang ada dalam dua keadaan. Pertama, karena penyakitnya, ia tidak kuasa berpuasa; ia wajib berbuka puasa. Kedua, orang sakit tapi kuat berpuasa. Akan tetapi, jika dalam pelaksanaannya diduga kuat ia akan mengalami kesulitan

\footnotetext{
${ }^{14}$ Juhaya S. Praja, Tafsir Hikmah Seputar Ibadah, Muamalah, Jin, dan Manusia, h. 75 
dan penyakitnya akan membahayakan dirinya, ia dianjurkan tidak berpuasa. $^{15}$

Sebagian ulama menyatakan bahwa penyakit apapun yang diderita oleh seseorang, membolehkannya untuk berbuka. Bahkan menurut Quraish Shihab, ulama besar Ibnu Sirin, pernah ditemui makan siang hari bulan Ramadan, dengan alasan jari telunjuknya sakit. Betapapun, harus dicatat, bahwa al-Qur'an tidak merinci persoalan ini. Teks ayat mencakup pemahaman Ibnu Sirin tersebut. Di sisi lain harus diingat bahwa orang yang tidak berpuasa dengan alasan sakit atau dalam perjalanan tetap harus mengganti hari-hari ketika ia tidak berpuasa dalam kesempatan yang lain. ${ }^{16}$

Sementara itu mengenai batas toleransi berbuka puasa bagi musafir terdapat keragaman penafsiran dan hukumnya. Hal ini bukan semata-mata berkenaan dengan penafsiran al-Qur'an, melainkan juga dengan penetapan hukum yang juga merujuk pada hadis-hadis Nabi saw. Seperti halnya kebolehan menjamak dan memperpendek salat bagi musafir diperuntukkan bagi mereka yang

\footnotetext{
${ }^{15}$ Juhaya S. Praja, Tafsir Hikmah Seputar Ibadah, Muamalah, Jin, dan Manusia, h. 76

${ }^{16}$ M.Quraish Shihab, Wawasan al-Qur'an, h. 525
} 
sedang melakukan perjalanan bukan untuk maksiat. Keragaman pendapat dan penetapan hukum kebolehan berbuka puasa bagi musafir ini terpulang kepada dua kubu pemikiran. Pemikiran pertama merujuk dan menitikberatkan pada jarak tempuh perjalanan. Pemikiran kedua, merujuk dan menitikberatkan pada tingkat kesulitan perjalanan itu sendiri. ${ }^{17}$

Ulama kubu pertama memberi batas minimal perjalanan yang membolehkan berbuka puasa; antara lain, jika perjalanan itu ditempuh sehari-semalam dengan berjalan kaki, atau perjalanan tersebut dipisahkan oleh lautan dan daratan. Ada pula yag memberi batas minimal 30 mil perjalanan. Kubu pemikiran kedua lebih menekankan pada tingkat kesulitan yang dialami si musafir selama perjalanannya dalam hubungannya dengan penunaian ibadah puasa tersebut. ${ }^{18}$

Keringanan dan kemudahan yang disebut rukhshah ${ }^{19}$ diberikan kepada mereka yang tidak kuasa lagi berpuasa karena

\footnotetext{
${ }^{17}$ Juhaya S. Praja, Tafsir Hikmah Seputar Ibadah, Muamalah, Jin, dan Manusia, h. 75

${ }^{18}$ Juhaya S. Praja, Tafsir Hikmah Seputar Ibadah, Muamalah, Jin, dan Manusia, h. 75

${ }^{19}$ Rukhshah secara bahasa berarti keringanan, kemudahan. Sedangkan menurut istilah, rukhshah adalah hukum yang ditetapkan yang menyalahi dalil syar'i atau qaidah umum karena adanya dalil syar'i yang lain. Rukhshah juga bisa diartikan sebagai kebolehan yang disyariatkan melakukan sesuatu yang
} 
usia tua. Mereka tidak wajib puasa tetapi harus membayar fidyah, ${ }^{20}$ yaitu memberi makan setiap hari kepada seorang miskin. Jumlah makanan yang diberikan kepada orang miskin itu sebanyak atau senilai biaya makanan si pembayar fidyah. Mereka tidak diwajibkan membayar puasa itu di hari yang lain, atau menqaadha' puasa itu.

وعلى الذين يطيقونه فدية طعام مسكين Pada penggalan ayat diperselisihkan maknanya oleh banyak ulama tafsir. Mayoritas ulama memahami penggalan ini berbicara tentang orang-orang tua atau yang memunyai pekerjaan yang sangat berat, sehingga puasa sangat memberatkannya, sedang ia tidak memunyai sumber rezeki lain kecuali pekerjaan itu. ${ }^{21}$

Ada hal yang menarik untuk disimak bersama ketika Mahmud Yunus menjelaskan ayat 185 dari surah al-Baqarah ini. Pada penggalan ayat faman syahida minkum al-Syahra terlarang untuk menghilangkan kesulitan/kesukaran. Qutb Mustafa Sanu, Mu'jam Mustalahat Ushul al-Fiqh ( Damsyiq: Dar al-Fikr, 2000), h. 217

${ }^{20}$ Mengenai takaran fidyah, ulama berbeda pendapat. Ada yang berpendapat sebanyak setengah sha' (gantang) atau kurang lebih 3,125 gram gandum atau kurma (makanan pokok). Ada juga yang menyatakan satu mud yakni sekitar 5/6 liter, dan ada lagi yang mengembalikan penentuan jumlahnya pada kebiasaan yang berlaku pada setiap masyarakat. M.Quraish Shihab, Wawasan al-Qur'an, h. 528

${ }^{21}$ M.Quraish Shihab, Wawasan al-Qur'an, h 528 
falyashumhu, ia menghubungkan ayat ini dengan sebuah kondisi yang terdapat di salah satu belahan bumi ini, yaitu di belahan kutub utara dan kutub selatan. ${ }^{22}$ Di Kutub Utara dan Kutub Selatan, lama siang dan malamnya berbeda dengan belahan bumi yang lain. Di sana siangnya selama 6 bulan demikian pula malamnya juga lamanya 6 bulan. Jadi, di Kutub Utara dan Kutub Selatan sehari semalam durasi waktunya satu tahun.

${ }^{22}$ Planet Bumi memiliki dua buah kutub, yaitu Kutub Utara di lautan Arktik dan Kutub Selatan di benua Antartika. Walau sama-sama daratan di ujung planet Bumi yang diliputi es, Kutub Utara dan Kutub Selatan memiliki banyak perbedaan. Penguin hanya salah satunya. Wilayah es di Arktik di Kutub Utara pada dasarnya merupakan lautan beku yang dikelilingi daratan yang sering disebut lingkaran Arktik (Arctic Circle). Sebaliknya, Antartika di Kutub Selatan adalah daratan benua dengan wilayah pegunungan dan danau berselimut es yang dikelilingi lautan. Benua Antartika mengandung hampir 90 persen es di seluruh dunia. Jika dicairkan, seluruh es Antartika cukup untuk memenuhi tiga perempat kebutuhan air minum di seluruh dunia. Benua Antartika jauh lebih dingin daripada Arktik sehingga bahkan terdapat lapisan es di sana yang tidak pernah meleleh sepanjang sejarah. Temperatur rata-ratanya -49 derajat Celcius. Suhu terdingin pernah tercatat pada 21 Juli 1983 sebesar -89,6 derajat Celcius di Stasiun Vostok, dekat kutub geomagnetik selatan. Sementara Arktik memilki temperatur rata-rata lebih tinggi sekitar -34 derajat Celcius. Sepanjang sejarah, Antartika memang tidak pernah dikuasai siapapun dan tidak ada penduduk di sana. Kontras sekali dengan wilayah lingkaran Arktik yang terdapat beberapa kota berpenduduk seperti Barrow di Alaska, Tromso, Norwegia, serta Muramansk dan Selekhaard, Rusia. Di Kutub Utaralah orang-orang Eskimo bermukim. Selain itu, hanya di Arktik saja beruang kutub bisa ditemukan secara alami. Mungkin ini juga alasan paling kuat mengapa penguin yang hanya ditemukan di Kutub Selatan tidak pernah menggunakan sayapnya untuk terbang. Hidup di wilayah kekuasaan masing-masing, penguin dan beruang kutub sama-sama makan ikan dan menempati puncak rantai http://berbagi10.blogspot.com/2013/02/10-perbedaan-kutub-utara-dan-kutub-selatan.html 
Dalam ilmu Astronomi, Bumi merupakan planet, secara urut planet-planet yang terdekat dari Matahari adalah Mercurius, Venus, Bumi, Mars, Yufiter, Saturnus, Uranus, Neptunus dan Pluto. Bumi beredar menurut sumbernya dengan kala rotasi 27,9 jam dan jarak Bumi Matahari kurang lebih 150 juta km. Gerakan rotasi Bumi ini akan memengaruhi keadaan cuaca di Bumi, misalnya terjadi siang dan malam, dengan pergantian waktu kurang lebih 12 jam, untuk daerah diantara 23,50 Lintang Utara dan Selatan, dan kurang lebih 6 bulan untuk daerah-daerah di sekitar Kutub Utara dan Kutub Selatan, dari tanggal 21 Maret s/d 21 September di daerah Kutub Utara mengalami siang hari dan di daerah Kutub Selatan mengalami malam hari, dari tanggal 21 September s/d 21 Maret di daerah Kutub Utara mengalami malam hari dan di daerah Kutub Selatan mengalami siang hari. Bumi beredar mengelilingi Matahari dengan skala revolusi 365,25 hari (1 tahun) ke arah anti clockwise (berlawanan arah jarum jam) dan dengan kecepatan edar rata-rata 18,5 mil/detik. Oleh karena ekliptika berbentuk elips, maka Matahari merupakan salah satu 
titik pusatnya, jadi jarak Bumi Matahari tidak selalu tetap melainkan berubah-ubah. ${ }^{23}$

Titik Perihelium ialah dimana Bumi beredar terdekat dengan Matahari, terjadi pada tanggal 21 Desember. Titik Aphelium ialah titik dimana Bumi berada terjauh dengan Matahari, terjadi pada tanggal 21 juni. Karena revolusi bumi dan miringnya sumbu Bumi terhadap ekliptika sebesar 66,50 mengakibatkan terjadinya perubahan musim di daerah yang terletak antara 23,50 Utara s/d Kutub Utara dan 23,50 Selatan s/d daerah Kutub Selatan. ${ }^{24}$

Tropic of Cancer adalah lingkaran lintang 23,50 Utara atau jajar yang melalui lintang 23,30 Utara, dan Tropic of Capricorn adalah lingkaran lintang 23,50 Selatan atau sejajar yang melalui lintang 23,50 Utara maka bagian belahan yang lain dari lintang 900-23,50 $=66.50$ ke Kutub tidak mendapatkan sinar Matahari. Jajar melalui lintang 66.50 Utara disebut Artic Circle dan jajar yang melalui lintang 66.50 Selatan disebut Artartic Circle atau lingkaran Kutub Utara dan Kutub Selatan. Setiap titik yang

${ }^{23}$ diakses pada tanggal 10 bulan Januari 2020 di website: http://us.yhs4.search yahoo.com/yhs

${ }^{24}$ diakses pada tanggal 10 bulan Januari 2020 di website http://us.yhs4.search yahoo.com/yhs 
terletak pada lintang 66.50 minimum mengalami gelap 1 hari dalam 1 tahun dan setiap titik di Kutub mengalami gelap 6 bulan dalam 1 tahun. ${ }^{25}$

Mahmud Yunus menjelaskan bahwa puasa itu wajib atas orang-orang yang berada dalam bulan ramadan yang lamanya 29 hari atau 30 hari. Karena di Kutub Utara dan Kutub Selatan lama harinya jauh melebihi 30 hari, maka disana tidak diwajibkan berpuasa. Ini dapat dipahami dari firman Allah yang menyatakan bahwa barang siapa diantara kamu yang menyaksikan bulan ramadan, hendaklah ia berpuasa. Jadi, karena di Kutub Utara dan Kutub Selatan tidak ada bulan ramadan, maka di sana tidak diwajibkan berpuasa. ${ }^{26}$

Menarik untuk diketahui juga bahwa kebanyakan ulama memahami penggalan ayat وعلى الذين يطيقونه فدية طعام مسكين(dan orang yang berat menjalankan puasa itu membayar fidyah), hanya kepada orang-orang tua dan orang yang memunyai pekerjaaan berat. Mayoritas ulama memahami maksud ayat ini bahwa orang yang boleh tidak berpuasa tetapi ia harus membayar fidyah, hanya

\footnotetext{
${ }^{25}$ diakses pada tanggal 10 bulan Januari 2020 di website http://us.yhs4.search yahoo.com/yhs

${ }^{26}$ Mahmud Yunus, Tafsir Qur'an Karim, h. 38
} 
kepada orang-orang tua dan orang-orang yang memunyai pekerjaan berat misalnya, buruh bangunan saja.

Dalam perkembangan zaman dengan semakin pesatnya ilmu pengetahuan yang dimiliki manusia, ternyata ada sebuah fakta ilmiah yang ditemukan bahwa di Kutub Utara dan Kutub Selatan ada suatu kondisi ekstrim yang memungkinkan manusia tidak dapat menjalankan puasa ramadan sebagaimana mestinya.

Menurut Wahbah al-Zuhaili dalam kitab tafsirnya al-Tafsir al-Munir, dikatakan bahwa bagi orang-orang yang tinggal di Kutub Utara dan Kutub Selatan, maka cara pelaksanaan puasa di daerah tersebut adalah merujuk kepada daerah yang paling dekat dengannya, atau juga bisa merujuk kepada Mekah dan Madinah yang merupakan dua daerah awal terjadinya syariat. ${ }^{27}$

Tetapi kemusykilan terjadi jika cara melaksanakan puasa di daerah Kutub Utara dan Selatan adalah dengan merujuk kepada negeri yang terdekat atau ke Mekah dan Madinah. Kemusykilannya adalah terdapat batasan dari pengertian puasa yang dikemukakan oleh para ulama itu sendiri. Pengertian puasa

${ }^{27}$ Wahbah al-Zuhailiy, al-Tafsir al-Munir fi al-Aqidah wa al-Syari'ah wa al-Manhaj Juz I ( Cet. I; Damsyik:Dar al-Fikr, 1411 H/1991 M), h. 135 
menurut kesepakatan para Ulama adalah berniat menahan makan dan minum serta tidak melakukan hubungan suami istri dimulai dari terbit fajar sampai terbenam matahari. ${ }^{28}$ Di Kutub Utara dan Selatan, terbenamnya matahari harus menunggu sampai 6 bulan. Bagaimana mungkin orang berbuka puasa padahal mataharinya belum terbenam ?.

Mahmud Yunus hendak menyatakan bahwa sebagaimana orang yang sakit dan orang yang memiliki pekerjaan berat boleh tidak menunaikan ibadah puasa ramadan tetapi membayar fidyah, maka orang yang berada di Kutub Utara dan Selatan juga boleh tidak berpuasa karena wilayah tersebut tidak mungkin untuk dapat melaksanakan puasa ramadan. Dengan kata lain tinggal di dua daerah Kutub tersebut, termasuk kategori orang-orang yang cukup berat untuk menjalankan puasa ramadan.

Akhirnya menurut Mahmud Yunus, fenomena alam seperti yang terjadi di Kutub Utara dan Selatan tersebut, semakin membuktikan bahwa al-Qur'an itu bukanlah karangan Nabi Muhammad saw. melainkan semata-mata adalah wahyu dari Allah swt. Ia menulis :

Disini terang benar, bahwa Qur'an itu bukanlah karangan Nabi Muhammad melainkan semata-2 wahyu dari pada

\footnotetext{
${ }^{28}$ Wahbah al-Zuhailiy, al-Tafsir al-Munir fi al-Aqidah wa al-Syari'ah wa al-Manhaj Juz I, h. 128
} 
Allah. Karena karangan seseorang mestilah menurut yang sesuai dengan tanah airnya, masanya dan pengetahuan pada waktu itu. Tetapi Qur'an dapat bersesuaian dengan segala tempat dan masa, sekalipun ilmu pengetahuan telah bertambah tinggi. $^{29}$

Memang, zaman modern merupakan era penyesuaian yang cukup signifikan dan mencolok seiring dengan kemajuan ilmu pengetahuan dan teknologi. Penyesuaian-penyesuaian tersebut terutama untuk membuktikan bahwa al-Qur'an itu benar-benar sesuai dengan segala tempat dan zaman.

\section{Kesimpulan}

Demikianlah salah satu penafsiran saintifik Mahmud Yunus yang ditemukan dalam karya Tafsirnya. Dalam setiap penafsiran ilmiah terhadap suatu ayat, Mahmud Yunus selalu mengakhirinya dengan sebuah seruan kepada umat Islam untuk menguasai ilmu pengetahuan modern. Mahmud Yunus hendak menyatakan bahwa umat Islam harus menjadi kaum yang terdepan dalam hal penguasaan ilmu pengetahuan modern. Berkali-kali ia mengingatkan bahwa jauh sebelum ulama-ulama Eropa - demikian ia menulis dalam tafsirnya - menguasai ilmu pengetahuan ilmiah modern, islam sudah lebih dahulu membicarakannya dalam kitab

\footnotetext{
${ }^{29}$ Mahmud Yunus, Tafsir Quran Karim, h. 38
} 
suci al-Qur'an. Oleh karena itu, menjadi aneh jika umat Islam hanya menjadi penonton ditengah-tengah pesatnya perkembangan ilmu pengetahuan modern.

Model tafsir saintifiknya Mahmud Yunus adalah memanfaatkan pengetahuan-pengetahuan ilmiah modern (sains) yang sedang berkembang untuk tujuan memahami dan menjelaskan ayat-ayat al-Qur'an. Bukan ayat-ayat al-Qur'an dicocok-cocokkan dengan ilmu pengetahuan modern. Hemat penulis, tidaklah keliru jika dikatakan bahwa Mahmud Yunus adalah mufasir pertama indonesia yang memasukkan penafsiranpenafsiran saintifik dalam karya tafsirnya. 


\section{DAFTAR PUSTAKA}

Amal, Taufik Adnan, Rekonstruksi Sejarah al-Qur'an Yogyakarta: FkBA, 2001

Hitami, Munzir, Pengantar Studi Al-Qur'an: Teori dan Pendekatan Cet I; Yogyakarta:Lkis, 2012.

Jauhari, Tantawi, al-Jawahir fi Tafsir al-Qur'an al-Karim, Juz I, Cet. II; Kairo: Mu'assasah Mustafa al-Babi al-Halabi, 1350

Mattson, Ingrid, The Story of the Qur'an, diterjemahkan oleh R. Cecep Lukman Hakim dengan judul Ulumul Quran Zaman Kita: Pengantar untuk Memahami Konteks, Kisah, dan Sejarah Al-Qur'an Cet. I; Jakarta: Zaman, 2013.

Mustaqim, Abdul, Epistemologi Tafsir Kontemporer Cet.III;Yogyakarta:LKiS, 2012.

Praja, Juhaya S, Tafsir Hikmah Seputar Ibadah, Muamalah, Jin, dan Manusia Cet. I; Bandung; PT Remaja Rosdakarya, 2000 .

Sanu, Qutb Mustafa, Mu'jam Mustalahat Ushul al-Fiqh Damsyiq: Dar al-Fikr, 2000.

Shihab, M.Quraish, Wawasan al-Qur'an: tafsir Maudhu'i atas pelbagai Persoalan Cet.IV; Bandung: Mizan, 1996.

Soleh, Achmad Khudori, Bint al-Syathi': Tafsir Tematik dalam Pemikiran Islam Kontemporer Cet. I; Yogyakarta: Jendela: 2003. 
Yunus, Mahmud, Riwayat Hidup Prof.Dr.H.Mahmud Yunus, 10 Pebruari 1899-16 Januari 1982 Jakarta: Hidakarya Agung, 1982

, Sejarah Pendidikan Islam di Indonesia Jakarta:Hidakarya Agung, 1996.

Tafsir Quran Karim Cet VIII; Kuala Lumpur: Klang Book Centre, 2004.

Yusuf, M.Yunan, Karakteristik Tafsir al-Qur'an di Indonesia abad ke $X X$. Dalam Jurnal Ulum al-Qur'an vol. III, No.4. Tahun 1992.

al-Zahabi, Muhammad Husain, al-Tafsir wa al-Mufassirun Jilid III Mesir: Dar al-Kutub al-Hadis, 1961 